\title{
DEBATE
}

\section{causal description: moving beyond stamp collecting in political science}

\author{
gerald schneider \\ Department of Politics and Management, University of Konstanz, PO Box D 86, \\ Konstanz D-78457, Germany. \\ E-mail: gerald.schneider@uni-konstanz.de
}

doi:10.1057/eps.2009.49

\begin{abstract}
The articles by Kees van Kersbergen and Daniele Caramani constitute an impressive joint plea in favour of descriptive analyses within comparative politics. They also warn, less convincingly, against an alleged obsession of the discipline with variation that, according to them, does not do justice to the similarity of many cases. This response demonstrates that limiting the analysis to similar cases creates the risk of engaging in the hapless exercise of explaining the constant. Augmenting the role of description without simultaneously advancing sound theoretical models furthermore leads to theory-free data mining exercises. I argue that all empirically oriented fields in political science could profit from what I call 'causal description' and hence the in-depth univariate analysis of the dependent variable.
\end{abstract}

Keywords comparative politics; political theory; rational choice; covariation

\section{INTRODUCTION}

ord Ernest Rutherford's famous quip that 'All science is either physics or stamp collecting' makes the important distinction between theory-free data collection exercises and attempts to link sophisticated theoretical and empirical models in a rigorous fashion. Most readers would probably agree that we have nowadays - despite the anti-scientific flagellantism of the Perestroika movement within the American Political

\begin{abstract}
Science Association and its European fellow travellers - moved far beyond 'stamp collecting' in the social sciences and link theory in meaningful ways to data. Some might even agree that we have uncovered in these attempts an amazing number of non-trivial laws and empirical regularities over the past few years. This success is, not in the least, due to the rationalist revolution that has been shaking US political science, parts of its British counterpart and even some isolated corners in continental European
\end{abstract}


academia since the 1980s (Schneider, $2007,2009)$. One key event in this largely institutionalist movement has been Black's (1948) discovery of the median voter theorem and subsequent innovations like the development of coalition and rent-seeking approaches or the advancement of political business cycle theory and bureaucratic politics models. The scientific progress has in the meantime even reached my main area of research, international relations, and thus a subfield that is conceptually rather conservative. The sound theoretical underpinnings that have been developed within this research area to account for what is called the 'democratic peace' demonstrate in an exemplary fashion what we have achieved. Innovations by Schultz (1999), Fearon (1994) and others show that we have gone way beyond the correlational analyses of the 1960s, the chronological narration of some arbitrarily selected cases or the trivial commentaries by the inevitable TV wonks on what we, anyhow, just witnessed on BBC World, CNN or France 24.

Unfortunately, Rutherford's cynical remark quoted in the beginning of this article jumped back into my mind when I was reading the important and unusually deep papers by Daniele Caramani (2010) and Kees van Kersbergen (2010), henceforth DC and KvK, about the state of art in comparative politics. I should start out by saying that I agree with many points that they are making. I share, for instance, the sentiment voiced by $\mathrm{KvK}$ that there is too much loose speculation about the end of the state and the imminent emergence of world government. To paraphrase Mark Twain, the death of territorial sovereignty has been announced much too prematurely and exaggeratedly. Not least the slaughtering of civil liberties around the globe since the terrorist attacks on the United States and its allies amply and sadly demonstrates that governments are still much stronger than we ever wished

\section{'we have nowadays moved far beyond "stamp collecting" in the social sciences and link theory in meaningful ways to data'}

them to be. I also share the impression of DC that the research community should reward sound descriptive work much more; we all too often follow the easy road and produce conjectures that are not firmly grounded in a theoretically solid assessment of past and current trends in political decision making.

But I want to cut my jubilation short and get down to business. I assume at any rate that the editors of this journal did not invite me to bore the reader with a trite exercise in diplomacy. They probably rather wish to see the 'diehard rationalist', as I branded myself at some point (Aspinwall and Schneider, 2000: 30), to dissect some of the claims made in the two related articles. I happily pursue this task and take issue with the way in which the authors want to move comparative politics towards similarity analyses. In essence, I believe that the bête noire of $\mathrm{DC}$ and $\mathrm{KvK}$ - variation - will remain the backbone of any scientific enterprise in the social sciences. I will come back to this point after a 'discourse' analysis of the two articles and after pointing out that the two pieces under consideration ultimately attempt to explain the inexplicable - the constant. I will then also clarify that we need 'causal description' and thus the univariate analysis of a concept that is part of a strong theoretical argument.

\section{A RATHER CONSERVATIVE ALTERNATIVE TO CURRENT POLITICAL SCIENCE}

Both DC and KvK advocate that comparative politics - and probably all the other

gerald schneider european political science: 92010 
subfields in political science - restrict their analyses to the careful examination of similar cases and devote more energy to sensible description. This is, on the surface, a sympathetic criticism as we all too often sin and extend our comparisons to the juxtaposition of apples and oranges and hence cases that should really not be pitted against each other. The articles also rightly point out that much political science research has recently started to suffer under the teleological illusion that the world converges to one sort of political, economic or ideological system. This smacks of the 'Endism' that Fukuyama (1992) popularized in the 1990s and that heralded the ultimate triumph of capitalism, democracy and other goodies then attributable to the United States. ${ }^{1}$

Although I share the aversion of both authors against such haughtiness, I will, nevertheless, take issue with the surprisingly conservative tone that underlies their plea to engage in similarity analyses and descriptive work. To start with, the articles by DC and KvK implicitly suggest that we should move the wheel back in comparative politics. The authors describe an idealized time during which researchers cared more about research designs, when they restricted their analyses to a selection of cases that can be sensibly compared and when the political science community seemingly did not shy away from unrewarding descriptive work. Yet, did this idealized world ever exist? I am sure that this is just a collective mirage that overestimates the scientific achievements of past generations and does not take into account the immense progress that political science has experienced over the past few years. As any reader, even the most casual one, of leadings journals such as APSR, AJPS, $B J P S, J C R$, JOP or IO would easily acknowledge, our knowledge of political processes has recently grown exponentially, notwithstanding the occasional call that the discipline has lost its soul. The technical skills that average (US trained) political scientists have gained nowadays is far beyond the level of sophistication that even the most influential scholars of the 1960s and 1970s had ever achieved, and the proliferation of new estimators and conceptual innovations is truly immense and indicates that we live in a healthy academic community.

As, at least, KvK makes clear, his next door paradise is the behaviouralist period of the 1960s that preceded the rational choice movement. In his view, current political science is overly institutionalist and does not pay sufficient attention to social factors. This objection is, however, reductionist as at least the rationalist variant of neo-instiutionalism takes into account the interplay between institutions and preferences, be they socially or economically based (Aspinwall and Schneider, 2000). Rational choice institutionalism, in other words, perceives politics as a social interaction in which actors pursue their interests, given the restrictions and opportunities of the institutional setting. Lamenting over explanations that only take these rules of the game into account intellectually does not surpass theories that trace political behaviour exclusively back to the social characteristics of a group or an individual. What we need in political science are rather parsimonious but complete explanations that consist, at least, of interests and institutions. These causal mechanisms might, in some contexts, be augmented by the informational level that an actor has about the situation in which she finds herself or, related to this, the ideas that shape her decisions (Schneider, 2003). Hence, I sincerely recommend that we not move back to a time when Plott's 'fundamental equation of politics' (Hinich and Munger, 1997: 17), according to which political outcomes are a function of preferences and institutions, was not yet fully recognized as the unifying conceptual basis in political science. 


\section{THE PITFALLS OF SIMILARITY ANALYSES AND A PLEA FOR THEORETICAL DESCRIPTION}

Both DC and KvK call for research designs that stress the similarities between the units of analysis rather than the differences. As KvK (2009: 9) puts it, 'there is a fixation on variation'. Differences are obviously a matter of degree, but I fail to see whether similarity and variation designs really differ. It depends probably a great deal on the underlying scale and whether we perceive cases to be sufficiently different from each other to allow meaningful comparisons. In other words, I believe that variation is the backbone of any science, and we should not be disturbed by the senseless sampling of cases in some applications to abandon completely our scientific goals. The main insight of the King et al (1994) volume was to show that comparison is the backbone of quantitative and qualitative research in political science. Hence, whatever methodological orientation, we all seek to explain how an outcome variable varies given a change in the explanatory concept. If no change occurs, given some variation on the independent variable, the dependent variable stays at the level of the constant. In other words, we cannot explain anything at all in comparative politics and beyond if we do not assume a minimal covariance between the two concepts under scrutiny.

The attack on variational analyses in both articles is accompanied by a call for descriptive analyses. I fully admit that the creation of new data sets and the provision of similar public goods are often not sufficiently acknowledged research efforts nowadays. But, again, has the pursuit of a common good instead of much narrower objectives such as the individual publication success or the collection of bonus miles ever been rewarded? I have my severe doubts

\section{'variation is the backbone of any science'}

whether the contribution to the public good aspects of our discipline was really ever different, especially in the light of efforts to create a standard for data set citations and the growing importance of replication studies (King, 2007). Glancing through old volumes of leadings journals leaves me the impression that the situation in political science was 20 years back much the same as it is nowadays, notwithstanding the increase in employment opportunities and the proliferation in publication possibilities that European political science has recently witnessed. In other words, the professional game that we play has not changed much, and the old Adams and Eves, who we all are, face similar incentives to engage in shortterm analyses and chatty, non-rigorous research like 20 or 30 years ago! ${ }^{2}$ Admittedly, the political science market does not always work efficiently; some people who do first class work do not, for instance, receive the professional recognition they deserve. But I believe that the increasing transnational competition within our discipline produces better results than the programmatic straightjackets into which DC and KvK want to force European political science.

'Getting one's hands dirty', as DC recommends, is only a commendable endeavour if we know where to dig and where to get muddy. Unfortunately, neither article is very clear in saying what sort of descriptive analysis they would like to see more of in our publications. I have the strong suspicion, at least in DC's case, that he wants to have more data collection effort. However, I would like strongly to warn against a separation between theoretical progress and attempts to improve the empirical basis on which these theories must ultimately rely. 
Hence, theoretical and empirical work have to go hand in hand, especially considering that there is no such thing as theory-free description. In other words, what we need is much more space given to careful descriptive work that is truly inspired by rigorous theoretical thinking. I believe that such 'causal description' needs to precede any inferential research. However, there is no atheoretical evidence, as Popper taught us a long time ago, and the collection of data for its own sake is not an activity that we should encourage or reward.

\section{CONCLUSION}

Like any other mature discipline, political science periodically experiences some of its prominent members reflecting on the state of the discipline in an insightful, but also culturally pessimistic manner. Hence, these critical pieces risk falling in the trap of identifying isolated excesses and superficialities as symptoms of a general illness that only some traditional therapy can cure. I believe, unfortunately, that this is exactly the risk that these two articles failed to avoid.

To put it into medical terminology, KvK and DC recommend in their articles that political science can only recover from its current weakness through a triple medication - a return to political sociology, increasing attention paid to description, and a narrower focus on similar cases. I believe that the patient- political science is much healthier than the two articles suggest and thus does not need to swallow this super-pill manufactured by a Swiss-Dutch joint venture. We have seen in recent years a proliferation of rigorous theoretical thinking and sophisticated testing strategies, suggesting that we do not really have to be too pessimistic about our discipline having weakened and lost its main purpose. This does not mean that we would suffer under small drops of the KvK and DC magic potion. On

\section{'theoretical and empirical work have to go hand in hand'}

the contrary, the achievement of their articles is to point out that comparing the incomparable (i.e. designs with artificially high variation across cases) is a serious failure in many applications. They are also right in pointing out that 'quick and dirty' inferential research frequently does not rely on a solid descriptive foundation, and it is correct to say that some institutionalist analyses do not pay sufficient tribute to the social (or economic) roots of decision making.

However, this first development of the KVK and DC regimen literally risks harming the patient more than any placebo they could possibly have handed out. The consequential application of the similarity analyses that the authors suggest would kill any interesting variation among the cases, rendering comparative politics a superfluous exercise as there would be nothing to be compared any longer. Further, to engage into descriptive work for its own sake borders on the attempt to open a vault without the help of a key. As Rutherford has put it, theory-free empiricism will not help us to understand the world and is nothing else than stamp collecting. I am much more convinced than KvK and DC that we already possess some important keys that help us to understand the world of politics. We should, of course, also get our hands dirty by engaging in carefully descriptive and inferential empirical work but, first and foremost, by advancing rigorous theoretical thinking about political affairs.

\section{Acknowledgements}

I thank Michael Bechtel and Roos van der Haer for comments on an earlier draft. 


\section{Notes}

1 If such bold predictions were ever to be true, the sad, but necessary consequence would be the imminent abolition of comparative politics altogether.

2 This response is, unfortunately, no exception to this. I hope that at least some of my publications live up to the standard that I am preaching here.

\section{References}

Aspinwall, M.D. and Schneider, G. (2000) "Same menu, separate tables: The institutionalist turn in political science and the study of European integration', European Journal of Political Research 38(1): $1-36$.

Caramani, D. (2010) 'Of differences and similarities: Is the explanation of variation a limitation to (or of) comparative analysis?', European Political Science 9(1): 34-48.

Fearon, J.D. (1994) 'Domestic political audiences and the escalation of international disputes', American Political Science Review 88(3): 577-592.

Fukuyama, F. (1992) The End of History and the Last Man, New York: Free Press.

Hinich, M.J. and Munger, M.C. (1997) Analytical Politics, Cambridge: Cambridge University Press.

King, G. (2007) 'An introduction to the dataverse network as an infrastructure for data sharing', Sociological Methods and Research 32(2): 173-199.

King, G., Keohane, R.O. and Verba, S. (1994) Designing Social Inquiry, Princeton: Princeton University Press.

Schneider, G. (2003) 'Condorcets konstitutionelle Knacknuss. Probleme der politischen Beratung am Beispiel der BSE-Krise', in U. Serdült and T. Widmer (eds.) Politik im Fokus. Festschrift für Ulrich Klöti, Zürich: NZZ Verlag, pp. 383-401.

Schneider, G. (2007) 'Why is European political science so unproductive and what should be done about it: A symposium', European Political Science 6(2): 156-159.

Schneider, G. (2009) 'Qui a peur de John Nash? A propos de la place des approches de type 'choix rationnel' en Allemagne et en France', in S. Saurugger, D. Deschaux-Beaume and M. Delori (eds.) Le choix rationnel en science politique. Débats critiques, Paris: Presses universitaires de Rennes, pp. 71-85.

Schultz, K. (1999) 'Do democratic institutions constrain or inform?: Contrasting two institutional perspectives on democracy and war', International Organization 52(Spring): 233-266.

Van Kersbergen, K. (2010) 'Comparative politics: Some points for discussion', European Political Science 9(1): 49-61.

\section{About the Author}

Gerald Schneider is Professor of Political Science at the University of Konstanz, Germany, where he has held the International Relation Chair since 1997. He is also Executive Editor of European Union Politics and coordinator of the multi-disciplinary research initiative Science of Social Stress and Conflict Resolution. 